\title{
PENGARUH SUPERVISI MANAJERIAL KEPALA SEKOLAH DAN IKLIM ORGANISASI TERHADAP PRESTASI KERJA GURU SEKOLAH DASAR NEGERI PADA UNIT PELAKSANA TEKNIS DINAS PENDIDIKAN DI KECAMATAN CIAWIGEBANG KABUPATEN KUNINGAN
}

\author{
Sumirat ${ }^{1}$ \\ Wresni Pujiyati ${ }^{2}$
}

${ }^{1}$ Dinas Tenaga Kerja \& Transmigrasi Kabupaten Kuningan, Jawa Barat email: sumirat@ gmail.com

${ }^{2}$ Universitas Wiralodra, Jl. Ir. H. Juanda KM 3 Indramayu, Jawa Barat email: wresni.pujiyati@unwir.ac.id

\begin{abstract}
ABSTRAK
Tujuan penelitian ini untuk mengetahui dan menganalisis pengaruh supervisi manajerial dan iklim organisasi terhadap prestasi kerja guru SD Negeri pada UPTD Pendidikan di Kecamatan Ciawigebang Kabupaten Kuningan. Penelitian ini mengambil fokus utama untuk mengetahui besaran pengaruh supervisi manajerial kepala sekolah dan iklim organisasi baik secara parsial maupun ganda. Objek penelitian ini adalah guru SDN di UPTD Pendidikan Kecamatan Ciawigebang Kabupaten Kuningan.Metode penelitian ini menggunakan pendekatan kuantitatif, di mana penulis terjun langsung ke tataran empirik dengan menyebarkan angket terhadap 80 orang guru SD Negeri pada UPTD Pendidikan di Kecamatan Ciawigebang Kabupaten Kuningan sebagai responden. Adapun teknik pengolahan dan analisisnya menggunakan teknik regresi. Hasil penelitian menunjukkan, bahwa: (1) Terdapat pengaruh yang positif dan signifikan supervisi manajerial kepala sekolah terhadap prestasi kerja guru (2) Terdapat pengaruh yang positif dan signifikan iklim organisasi terhadap prestasi kerja guru (3) Terdapat pengaruh yang positif dan signifikan supervisi manajerial kepala sekolah dan iklim organisasi secara simultan terhadap prestasi kerja guru. Bertolak dari kesimpulan di atas, penulis menyarankan: (1) Kepala Dinas Pendidikan hendaknya memberikan pengawasan dan pembinaan yang berkelanjutan kepada seluruh kepala sekolah agar selalu berusaha meningkatkan kepemimpinannya dalam kaitan supervisi, dan melaksanakan kaidah manajerial dengan benar terutama menyangkut pengawasan sehingga dapat mendorong terwujudnya prestasi kerja guru yang terus berkembang. (2) hendaknya kepala sekolah memahami secara benar konsep supervisi dan petunjuk pelaksanaan kerja guru yang optimal.
\end{abstract}

Kata kunci: Supervisi Manajerial, Iklim Organisasi, Prestasi Kerja Guru

\begin{abstract}
The purpose of this study aims to determine and analyze the effect of managerial supervision and organizational climate on the work performance of elementary school teachers in UPTD Education in Ciawigebang District, Kuningan District. This research takes the main focus to find out the magnitude of the influence of the principal's managerial supervision and organizational climate both partially and double. The object of this research is SDN teachers in UPTD Education in Ciawigebang Subdistrict, Kuningan Regency. The method of this study uses a quantitative approach, in which the writer plunges directly into the empirical level by distributing questionnaires to 80 SD elementary school teachers in UPTD Education in Ciawigebang District, Kuningan Regency as respondents. The processing and analysis techniques use regression techniques. The results showed that: (1) There was a positive and significant influence on the managerial supervision of school principals on teacher work performance (2) There was a positive and significant influence on organizational climate on teacher work performance (3) There was a positive and significant influence on the managerial supervision of principals school and
\end{abstract}


organizational climate simultaneously towards teacher work performance. Based on the conclusions above, the authors suggest: (1) The Head of the Education Office should provide continuous supervision and guidance to all school principals in order to always try to improve their leadership in relation to supervision, and implement managerial rules with especially true regarding supervision so that it can encourage the realization of teacher work performance that continues to grow. (2) the principal should correctly understand the concept of supervision and instructions for the optimal implementation of teacher work.

Keywords: Managerial Supervision, Organizational Climate, Teacher Work Performance

\section{PENDAHULUAN}

Iklim organisasi merupakan lingkungan manusia dimana di dalamnya anggota organisasi melakukan pekerjaan mereka. Atau dengan kata lain iklim organisasi merupakan lingkungan manusia dimana mansuia bekerja. Iklim organisasi adalah seperangkat ciri atau atribut yang dirasakan individu dan yang dipertimbangkan berdampak pada keinginan individu untuk berprestasi sebagik-baiknya.

Penelitian terdahulu oleh Moon \& Choi (2014) menyatakan bahwa iklim etika organisasi bermanfaat bagi karyawan maupun organisasi. Pada penelitian oleh Moon dan Choi menunjukkan iklim etika organisasi secara positif terjait dengan kepuasan pelanggan serta kinerja keuangan.

Davis memaparkan bahwa Iklim organisasi juga dapat berupa persepsi individu tentang berbagai aspek yang ada dalam lingkungan organisasi. (Davis, 1982)
Beranjak dari paparan di atas, penulis menduga kuat bahwa supervisi manajerial dengan didukung oleh iklim organisasi yang nyaman dapat mendorong prestasi kerja guru meningkat.

Kebutuhan manusia diartikan sebagai sesuatu yang ingin dimiliki, dicapai dan dinikmatinya. Oleh karena itu, manusia terdorong untuk melakukan aktivitas yang disebut kerja. Tetapi tidak semua aktivitas dapat dikatakan kerja, karena yang dimaksud dengan pekerjaan adalah kegiatan yang direncanakan. Dengan demikian pekerjaan yang dilaksanakan memerlukan pemikiran dan kegiatan khusus yang secara sungguh-sungguh ditunjukan untuk mencapai suatu hasil, baik itu berupa benda, karya, tenaga maupun sebagai pelayan terhadap masyarakat, termasuk dirinya sendiri. (Anoraga, 2005).

Bekerja mengandung arti melaksanakan suatu tugas yang diakhiri dengan buah karya yang dapat dinikmati oleh manusia 
termasuk yang bersangkutan sendiri. Dalam pengertian yang paling sederhana, pekerjaan adalah sesuatu yang dilakukan seseorang untuk dapat memperoleh imbalan baik berupa uang atau balas jasa lain. Tujuan dari kerja adalah untuk hidup. Jadi setiap orang yang melakukan kegiatan fisik atau kegiatan kegiatan mental (otak) dengan mendapat imbalan sarana kebutuhan untuk hidup, berarti kerja. (Fraser, 2005)

- Pekerjaan diartikan sebagai kegiatan yang membutuhkan berbagai persyaratan kemampuan dan untuk itu biasanya yang pelakunya mendapat balas jasa dan kepuasan. Dari pengertian tersebut, ada tiga unsur yang perlu diperhatikan, yakni: kemampuan, balas jasa dan kepuasan, dengan demikian untuk melakukan suatu pekerjaan diperlukan kemampuan tertentu, berupa: muscular, sensory, mental, social dan conceptual (imaginative) sesuai dengan pendapat Nainggolan (2005).

Prestasi kerja adalah "hasil kerja yang dicapai oleh seorang tenaga kerja dalam melaksanakan tugas dan pekerjaan yang dibebankan kepadanya".(Musanef, 2005) Kinerja atau prestasi kerja sebagai hasil atau apa yang keluar (outcomes) dari sebuah pekerjaan dan kontribusi mereka pada organisasi. (Ruky, 2001)
Tujuan dari penilaian prestasi kerja yaitu : (1) meningkatkan prestasi kerja seseorang dengan memberikan kesempatan untuk memenuhi kebutuhan aktualisasi diri dalam kerangka pencapaian tujuan, (2) merangsang minat dalam pengembangan pribadi agar meningkatkan hasil karya dan prestasi serta potensi laten dengan cara memberi umpan balik tentang prestasi yang bersangkutan, (3) membantu menyusun program pengembangan dan pelatihan yang tepat guna, dan (4) sebagai pertimbangan obyektif dalam sistem penghargaan (reward-punishment). Dalam konteks organisasi, penilaian prestasi kerja juga sangat membantu pimpinan maupun program-program organisasi secara menyeluruh (Ruky, 2001).

Mitchel menjelaskan bahwa aspek aspek prestasi kerja yang dapat dijadikan ukuran dalam menilai prestasi kerja adalah: (1) quality of work kualitas hasil kerja, (2) Promptness ketepatan waktu, (3) Initiative prakarsa menyelesaikan tugas, (4) Capability kemampuan menyelesaikan tugas, dan (5) Comunication kemampuan menjalin kerjasama dengan pihak lain. (Sedarmayanti, 1998)

Boarmand et al menyatakan bahwa supervisi adalah suatu usaha untuk 
menstimulasi, mengkoordinasi dan membimbing secara kontinu pertumbuhan guru-guru disekolah baik secara individual maupun secara kolektif, agar lebih mengerti dan lebih efektif dalam emwujudkan seluruh fungsi pengjaran. (Sahertian, 2000)

Burton dan Bruckner dalam Purwanto (2007:77) menyatakan bahwa supervisi adalah "teknik pelayanan yang tujuan utamanya mempelajari dan memperbaiki secara bersama-sama faktor-faktor yang mempengaruhi pertumbuhan dan perkembangan anak.” (Purwanto, 2007)

Berdasarkan Peraturan Menteri Pendidikan Nasional Nomor 12 Tahun 2007 tentang Standar Pengawas Sekolah/Madrasah telah ditetapkan bahwa salah satu kompetensi pengawas adalah kompetensi manajerial yang meliputi: (1) menguasai metode, teknik dan prinsip-prinsip supervisi dalam rangka meningkatkan mutu pendidikan di sekolah; (2) Menyusun program kepengawasan berdasarkan visi ,misi, tujuan dan program pendidikan sekolah; (3) Menyusun metode kerja dan instrumen tugas pokok dan fungsi pengawasan di sekolah; (4) Menyusun laporan hasil-hasil pengawasan dan menindaklanjutinya untuk perbaikan program kepengawasan berikutnya di sekolah; (5) Membina kepala sekolah dalam pengelolaan dan administrasi satuan pendidikan berdasarkan manajemen peningkatan mutu pendidikan di sekolah; (6) Membina kepala sekolah dan guru dalam melaksanakan bimbingan konseling di sekolah; (7) Mendorong guru dan kepala sekolah dalam merefleksikan hasil-hasil yang dicapainya untuk menemukan kelebihan dan kekurangan dalam melaksanakan tugas pokoknya di sekolah.

Iklim kerja merupakan "lingkungan manusia di mana di dalamnya anggota organisasi melakukan pekerjaan mereka. Atau dengan kata lain iklim kerja merupakan lingkungan manusia di mana manusia bekerja." (Davis, 1982)

Berkenaan dengan iklim kerja ini terdapat dua tipe iklim kerja, yaitu iklim terbuka dan iklim tertutup. Ciri khusus iklim kerja yang terbuka antara lain: (1) perilaku kepala sekolah yang dinamis, yang menggerakkan lembaga melalui contoh perilaku yang nyata (trust); (2) samangat kerja yang tumbuh karena pemenuhan tugas maupun pemenuhan kebutuhan sosial (esprit) serta menekuni pekerjaan yang ditugaskan kepadanya. Iklim kerja tertutup sebenarnya merupakan antisitetis dari iklim yang terbuka dengan ciri trust dan esprit yang rendah serta disengagemen yang tinggi. Perbedaan iklim yang terbuka dan iklim 
yang tertutup terutama tampak pada esprit. trust dan perilaku kepala sekolah yang akrab dan bersahabat (consideration). (Ali, 1998)

Burhanuddin (1994:272) menyatakan bahwa iklim kerja dapat digolongkan sebagai berikut: a) Iklim terbuka yang melukiskan organisasi penuh semangat dan gaya hidup memberikan kepuasan pada anggota kelompok dalam memenhi kebutuhannya. B) Iklim bebas, melukiskan suasana organisasi di mana tindakan kepemimpinan datang pertama tama dari kelompok, kepuasan kerja sedikit. c) Iklim terkontrol, bercirikan "inpersonal" dan sangat mementingkan tugas, sementara kebutuhan anggota organisasi tidak diperhatikan. d) Iklim yang familiar (kekeluargaan) adalah suatu iklim yang terlalu bersifat manusiawi dan tidak terkontrol. e) Iklim kebapakan (paternal climate) adalah organisasi sedemikian rupa adanya penekanan bagi munculnya kegiatan kepemimpinan dari anggota organisasi. f) Iklim tertutup, para anggotanya biasanya bersikap acuh tak acuh atau masa bodoh.

\section{METODE PENELITIAN}

Populasi dalam penelitian ini adalah seluruh guru SD Negeri pada UPTD Pendidikan di Kecamatan Ciawigebang Kabupaten Kuningan yang berjumlah 415 orang. Teknik perhitungan sampel menggunakan Cluster Random Sampling. Dengan demikian, maka diperoleh jumlah sampel yaitu guru SD Negeri pada UPTD Pendidikan di Kecamatan Ciawigebang Kabupaten Kuningan sebanyak 80 orang. Kisi-kisi penelitian tercantum pada tabel 1.

\section{Tabel 1}

Operasionalisasi Variabel $X_{1}, X_{2}$, dan $Y$

\begin{tabular}{|c|c|c|c|}
\hline Variabel & Dimensi & Indikator & $\begin{array}{l}\text { No. } \\
\text { Item }\end{array}$ \\
\hline \multirow[t]{5}{*}{$\begin{array}{c}\text { Supervisi } \\
\text { Manajerial (X) } \\
\\
\text { (Sulthon } \\
\text { Masyhud, 2012) }\end{array}$} & 1. Memantau & $\begin{array}{l}\text { 1) Penjaminan/standar mutu pendidikan } \\
\text { 2) Penerimaan siswa baru } \\
\text { 3) Rapat guru dan staf } \\
\text { 4) Program pengembangan sekolah } \\
\text { 5) Administrasi dan manajemen sekolah }\end{array}$ & $\begin{array}{l}1 \\
2 \\
3 \\
4 \\
5\end{array}$ \\
\hline & & 6) Hubungan sekolah dengan masyarakat & \\
\hline & 2. Mensupervisi & $\begin{array}{l}\text { 1) Kinerja sekolah, Kasek dan guru } \\
\text { 2) Pelaksanaan kurikulum } \\
\text { 3) Penyelenggaraan administrasi sekolah }\end{array}$ & $\begin{array}{l}7 \\
8 \\
9\end{array}$ \\
\hline & 3. Menilai & $\begin{array}{l}\text { 1) Peningkatan mutu SDM sekolah } \\
\text { 2) Penyelenggaraan inovasi sekolah } \\
\text { 3) Akreditasi sekolah } \\
\text { 4) Pengadaan sumber daya pendidikan }\end{array}$ & $\begin{array}{l}10 \\
11 \\
12 \\
13\end{array}$ \\
\hline & 4. Membina & $\begin{array}{l}\text { 1) Tim kerja dan staf sekolah } \\
\text { 2) Kepala sekolah }\end{array}$ & $\begin{array}{l}14,15 \\
16,17\end{array}$ \\
\hline
\end{tabular}




\begin{tabular}{|c|c|c|c|}
\hline Variabel & Dimensi & Indikator & $\begin{array}{l}\text { No. } \\
\text { Item }\end{array}$ \\
\hline & 5. Melaporkan & $\begin{array}{l}\text { 1) Kinerja sekolah } \\
\text { 2) Kinerja kepala sekolah dan staf sekolah } \\
\text { 3) Standar mutu pendidikan dan } \\
\text { pencapaian sekolah } \\
\text { 4) Pelaksanaan dan hasil inovasi } \\
\text { pendidikan sekolah } \\
\text { 5) Tindak lanjut hasil pengawasan }\end{array}$ & $\begin{array}{l}18 \\
19 \\
20 \\
21 \\
22\end{array}$ \\
\hline \multirow[t]{3}{*}{$\begin{array}{c}\text { Iklim } \\
\text { Organisasi } \\
\text { (Cooke and } \\
\text { Nigel, 2005:92) }\end{array}$} & 1. Hakekat manusia & $\begin{array}{l}\text { 1) Pemenuhan perlengkapan kerja } \\
\text { 2) Fasilitas lingkungan kerja } \\
\text { 3) Kejelasan tugas/pekerjaan } \\
\text { 4) Tanggung jawab } \\
\text { 5) Kewenangan } \\
\text { 6) Kewajaran kompensasi } \\
\text { 7) Penataan ruangan } \\
\text { 8) Penataan peralatan }\end{array}$ & $\begin{array}{c}1 \\
2,3 \\
4 \\
5 \\
6 \\
7,8 \\
9 \\
10\end{array}$ \\
\hline & $\begin{array}{l}\text { 2. Hubungan } \\
\text { organisasional }\end{array}$ & $\begin{array}{l}\text { 1) Perintah } \\
\text { 2) Pelaporan } \\
\text { 3) Tugas khusus } \\
\text { 4) Saluran keluhan } \\
\text { 5) Diskusi masalah pekerjaan }\end{array}$ & $\begin{array}{l}11 \\
12 \\
13 \\
14 \\
15\end{array}$ \\
\hline & $\begin{array}{l}\text { 3. Hubungan antar } \\
\text { pribadi }\end{array}$ & $\begin{array}{l}\text { 1) Tegur sapa } \\
\text { 2) Saling mengunjungi } \\
\text { 3) Curahan hati } \\
\text { 4) Pendengar yang baik } \\
\text { 5) Empati sesama bawahan }\end{array}$ & $\begin{array}{l}16 \\
17 \\
18 \\
19 \\
20\end{array}$ \\
\hline \multirow{5}{*}{ (Ruky, 2001) } & Kualitas hasil kerja & $\begin{array}{l}\text { 1) Ketepatan hasil kerja } \\
\text { 2) Kemasan } \\
\text { 3) Kuantitas } \\
\text { 4) Pencapaian target } \\
\text { 5) Efisiensi }\end{array}$ & $\begin{array}{l}1 \\
2 \\
3 \\
4 \\
5\end{array}$ \\
\hline & Ketepatan waktu & $\begin{array}{l}\text { 1) Kewajaran waktu pengerjaan } \\
\text { 2) Pencapaian target waktu }\end{array}$ & $\begin{array}{l}6 \\
7\end{array}$ \\
\hline & $\begin{array}{l}\text { Inisiatif dalam } \\
\text { pekerjaan }\end{array}$ & $\begin{array}{l}\text { 1) Usulan } \\
\text { 2) Ide-ide } \\
\text { 3) Inovasi }\end{array}$ & $\begin{array}{c}8 \\
9 \\
10\end{array}$ \\
\hline & $\begin{array}{l}\text { Kemampuan } \\
\text { menyelesaikan tugas }\end{array}$ & $\begin{array}{l}\text { 1) Rutin } \\
\text { 2) Insidental } \\
\text { 3) Khusus } \\
\end{array}$ & $\begin{array}{l}11 \\
12 \\
13\end{array}$ \\
\hline & $\begin{array}{l}\text { Kemampuan } \\
\text { bekerjasama }\end{array}$ & $\begin{array}{l}\text { 1) Perencanaan } \\
\text { 2) Kerjasama tim } \\
\text { 3) Komitmen } \\
\text { 4) Pelaksanaan } \\
\text { 5) Pemecahan masalah }\end{array}$ & $\begin{array}{l}14 \\
15 \\
16 \\
17 \\
18\end{array}$ \\
\hline
\end{tabular}

Teknik pengolahan data pada penelitian ini menggunakan uji coba instrumen penelitian untuk melihat validitas instrumen penelitian. Setelah itu, dilakukan uji reliabilitas. Analisis data untuk pengujian hipotesis penelitian digunakan analisis regresi dan analisis korelasi.

HASIL DAN PEMBAHASAN 
Untuk mengetahui besaran pengaruh supervisi manajerial kepala sekolah (X1) secara individual (parsial) terhadap prestasi kerja guru (Y) dapat dilihat dari nilai t pada tabel Coefficients dibawah ini dengan kriteria pengujian jika tingkat signifikansi lebih kecil dari 0,05, maka hipotesis diterima. Adapun hasil pengujian hipotesis tersebut adalah tercantum pada tabel 2 sebagai berikut:

Tabel 2

\section{Uji Hipotesis ( $t$ ) Variabel $X_{1}$ terhadap $Y$}

\begin{tabular}{|c|c|c|c|c|c|c|}
\hline \multirow{2}{*}{\multicolumn{2}{|c|}{ Model }} & \multicolumn{2}{|c|}{$\begin{array}{c}\text { Unstandardized } \\
\text { Coefficients }\end{array}$} & \multirow{2}{*}{$\begin{array}{c}\begin{array}{c}\text { Standardized } \\
\text { Coefficients }\end{array} \\
\text { Beta }\end{array}$} & \multirow[b]{2}{*}{$\mathrm{t}$} & \multirow[b]{2}{*}{ Sig. } \\
\hline & & B & Std. Error & & & \\
\hline \multirow[t]{2}{*}{1} & (Constant) & 52,851 & 4,351 & & 12,148 & ,000 \\
\hline & Supervisi_Manajerial_X1 & ,139 & ,056 & ,270 & 2,473 & ,016 \\
\hline
\end{tabular}

Berdasarkan tabel hasil uji t diperoleh bahwa nilai thitung variabel supervisi manajerial kepala sekolah (X1) memiliki nilai sebesar $p$-value $0,000<0,05$ artinya berdistribusi signifikan. Kondisi demikian berarti supervisi manajerial kepala sekolah (X1) secara parsial berpengaruh terhadap prestasi kerja guru
(Y). Hal tersebut memiliki makna menerima hipotesis yang menyatakan : “Terdapat pengaruh positif dan signifikan supervisi manajerial kepala sekolah terhadap prestasi kerja guru pada SD Negeri pada UPTD Pendidikan di Kecamatan Ciawigebang Kabupaten Kuningan ".

Tabel 3

Signifikansi Pengaruh Variabel $\mathrm{X}_{1}$ terhadap Y

\begin{tabular}{|ll|r|r|r|r|r|}
\hline Model & & Sum of Squares & df & Mean Square & F & Sig. \\
\hline 1 & Regression & 232,092 & 1 & 232,092 & 6,116 &, $016^{\mathrm{b}}$ \\
& Residual & 2959,858 & 78 & 37,947 & & \\
& Total & 3191,950 & 79 & & & \\
\hline
\end{tabular}

Berdasarkan tabel hasil uji anova atau $\mathrm{F}$ test didapat Fhitung sebesar 6,116 dan nilai signifikansi $0,016<0,05$. Dengan demikian Ho ditolak artinya pengaruh supervisi manajerial kepala sekolah terhadap prestasi kerja guru pada SDN di UPTD Pendidikan Kecamatan 
Ciawigebang Kabupaten Kuningan adalah signifikan.

Selanjutnya untuk mengetahui seberapa besar pengaruh supervisi manajerial kepala sekolah terhadap prestasi kerja guru dapat dilihat dari hasil perhitungan koefesien determinasi pada tabel 4 dibawah ini:

Tabel 4

Besaran Pengaruh Variabel $X_{1}$ terhadap $Y$

\begin{tabular}{|l|r|r|r|r|}
\hline Model & $\mathrm{R}$ & $\mathrm{R}$ Square & \multicolumn{1}{|c|}{$\begin{array}{c}\text { Adjusted R } \\
\text { Square }\end{array}$} & $\begin{array}{c}\text { Std. Error of the } \\
\text { Estimate }\end{array}$ \\
\hline 1 &, $270^{\mathrm{a}}$ &, 073 &, 061 & 6,160 \\
\hline
\end{tabular}

Dari tabel di atas terlihat bahwa R Square sebesar 0,073, hal ini berarti bahwa 7,3\% prestasi kerja guru dipengaruhi oleh variabel supervisi manajerial kepala sekolah, sedangkan sisanya $92,7 \%$ dipengaruhi oleh faktor lain yang tidak diteliti. Untuk mengetahui besaran pengaruh iklim organisasi (X2) secara individual (parsial) terhadap prestasi kerja guru $(\mathrm{Y})$ dapat dilihat dari nilai $\mathrm{t}$ pada tabel Coefficients dibawah ini dengan kriteria pengujian jika tingkat signifikansi lebih kecil dari 0,05, maka hipotesis diterima. Adapun hasil pengujian hipotesis tersebut adalah sebagai berikut tabel 5 .

Tabel 5

\section{Uji Hipotesis ( $t$ ) Variabel $X_{2}$ terhadap $Y$}

\begin{tabular}{|c|c|c|c|c|c|c|}
\hline \multirow{2}{*}{\multicolumn{2}{|c|}{ Model }} & \multicolumn{2}{|c|}{$\begin{array}{c}\text { Unstandardized } \\
\text { Coefficients }\end{array}$} & \multirow{2}{*}{$\begin{array}{c}\begin{array}{c}\text { Standardized } \\
\text { Coefficients }\end{array} \\
\text { Beta }\end{array}$} & \multirow[b]{2}{*}{$\mathrm{t}$} & \multirow[b]{2}{*}{ Sig. } \\
\hline & & $\mathrm{B}$ & Std. Error & & & \\
\hline \multirow[t]{2}{*}{1} & (Constant) & 53,178 & 4,583 & & 11,603 &, 000 \\
\hline & Iklim_Organisasi_X2 & , 144 &, 064 & ,249 & 2,273 & ,026 \\
\hline
\end{tabular}

Berdasarkan tabel hasil uji $\mathrm{t}$ diperoleh bahwa nilai thitung variabel iklim organisasi (X2) memiliki nilai sebesar pvalue $0,000<0,05$ artinya signifikan. Dengan demikian iklim organisasi (X2) secara parsial berpengaruh terhadap prestasi kerja guru (Y). Hal tersebut mengandung makna diterimanya hipotesis yang menyatakan: "Terdapat pengaruh positif dan signifikan iklim 
organisasi terhadap prestasi kerja guru pada SDN di UPTD Pendidikan Kecamatan Ciawigebang Kabupaten Kuningan ".

Persamaan regresi $\mathrm{y}=\mathrm{a} \mathrm{bx} 2$ dari hasil perhitungan diperoleh $\mathrm{y}=53,178+$ 0,144X2. Konstanta sebesar 53,178 menyatakan bahwa jika ada kenaikan nilai dari variabel iklim organisasi (X2), maka prestasi kerja guru (Y) adalah 53,178. Koefesien regresi sebesar 0,144 menyatakan bahwa setiap perubahan satu

skor atau iklim organisasi akan memberikan skor 0,144.

Untuk mengetahui besaran pengaruh supervisi manajerial kepala sekolah (X1) dan iklim organisasi secara bersamasama (ganda) terhadap prestasi kerja guru (Y) dapat dilihat dari nilai t pada tabel Coefficients dibawah ini dengan kriteria pengujian jika tingkat signifikansi lebih kecil dari 0,05, maka hipotesis diterima. Adapun hasil pengujian hipotesis tersebut adalah sebagai berikut tercantum pada tabel 6.

\section{Tabel 6}

Uji Hipotesis ( $t$ ) Variabel $X_{1}$ dan $X_{2}$ terhadap $Y$

\begin{tabular}{|c|c|c|c|c|c|c|}
\hline \multirow{2}{*}{\multicolumn{2}{|c|}{ Model }} & \multicolumn{2}{|c|}{$\begin{array}{c}\text { Unstandardized } \\
\text { Coefficients }\end{array}$} & \multirow{2}{*}{$\begin{array}{c}\text { Standardized } \\
\text { Coefficients } \\
\text { Beta } \\
\end{array}$} & \multirow[b]{2}{*}{$\mathrm{t}$} & \multirow[b]{2}{*}{ Sig. } \\
\hline & & $\mathrm{B}$ & Std. Error & & & \\
\hline \multirow[t]{3}{*}{1} & (Constant) & 43,098 & 6,022 & & 7,156 &, 000 \\
\hline & Supervisi_Manajerial_X1 &, 135 &, 055 & ,263 & 2,477 &, 015 \\
\hline & Iklim_Organisasi_X2 &, 140 & ,062 & ,242 & 2,280 & 025 \\
\hline
\end{tabular}

Berdasarkan tabel hasil uji t diperoleh bahwa nilai t hitung variabel supervisi manajerial kepala sekolah (X1) dan iklim organisasi (X2) secara bersama-sama (simultan) memiliki nilai sebesar $\mathrm{p}$-value $0,000<0,05$ artinya signifikan. Dengan demikian supervisi manajerial kepala sekolah (X1) dan iklim organisasi (X2) secara bersama-sama (simultan) berpengaruh terhadap prestasi kerja guru (Y). Hal tersebut membuktikan diterimanya hipotesis yang menyatakan: "Terdapat pengaruh positif dan signifikan supervisi manajerial kepala sekolah dan iklim organisasi secara bersama-sama terhadap prestasi kerja guru pada SDN di UPTD Pendidikan Kecamatan Ciawigebang Kabupaten Kuningan ”. Untuk mengetahui persamaan regresi dapat dilihat dari tabel di atas. Berdasarkan tabel tersebut menunjukkan persamaan regresi linier ganda: $\hat{Y}=$ 
43,098 + 0,135X1+0,140X2. Persamaan tersebut menyatakan bahwa setiap penambahan X1 dan X2 sebesar 1 maka akan meningkatkan Y sebesar 0,135 dan 0,140, artinya setiap peningkatan supervisi manajerial kepala sekolah dan iklim organisasi sebesar 1, akan meningkatkan prestasi kerja guru sebesar 0,135 dan 0,140 .

Permasalahan yang ingin dijawab dalam penelitian ini adalah pertama, adakah pengaruh pelaksanaan supervisi manajerial kepala sekolah terhadap prestasi kerja guru pada SDN di UPTD Pendidikan Kecamatan Ciawigebang Kabupaten Kuningan. Secara empirik, hasil penelitian ini menginformasikan: (1) terdapat pengaruh yang positif dan signifikan supervisi manajerial kepala sekolah terhadap prestasi kerja guru pada SDN di UPTD Pendidikan Kecamatan Ciawigebang Kabupaten Kuningan, serta (2) besarnya pengaruh supervisi manajerial kepala sekolah terhadap prestasi kerja guru pada SDN di UPTD Pendidikan Kecamatan Ciawigebang Kabupaten Kuningan ditunjukkan oleh hasil penelitian bahwa supervisi manajerial kepala sekolah yang terdiri dari dimensi: (1) memantau, (2) mensupervisi, (3) menilai, (4) membina, dan (5) melaporkan (Masyhud, 2012), membawa implikasi yang signifikan terhadap prestasi kerja guru yang meliputi dimensi: (1) kualitas hasil kerja, (2) ketepatan waktu, (3) inisiatif dalam pekerjaan, kemampuan menyelesaikan tugas, dan (5) kemampuan bekerjasama (Mitchel dalam Sedarmayanti, 1998:51). Namun demikian prestasi kerja guru pada SDN di UPTD Pendidikan Kecamatan Ciawigebang Kabupaten Kuningan ini tidak hanya dipengaruhi oleh supervisi manajerial kepala sekolah saja, ada faktor lain (epsilon), selain iklim organisasi, yang juga berpengaruh, yang tidak dikaji dalam penelitian ini.

Dalam perspektif supervisi untuk meningkatkan kemampuan profesional guru, Williams (2005:35), sebagaimana yang dialih bahasakan oleh Sumarno, berpendapat bahwa 'supervisi kelas yang dilakukan secara profesional akan sangat membantu dalam peningkatan kemampuan guru agar mereka dapat mengajar dengan baik.' Dengan begitu, akan diketahui segi-segi kelebihan dan kekurangan guru, selain untuk perbaikan, juga untuk bahan pertimbangan bagi keperluan pemberian motivasi, penghargaan, atau pujian bagi mereka yang layak menerimanya.

Dengan demikian, hasil penelitian ini mengindikasikan bahwa semakin bagus supervisi manajerial kepala sekolah yang 
dilaksanakan pada SDN di UPTD Pendidikan Kecamatan Ciawigebang Kabupaten Kuningan, maka akan diikuti oleh semakin tingginya prestasi kerja guru. Hal ini dapat diterangkan oleh persamaan regresi $\mathrm{y}=52,851+$ 0,139X1. Dengan persamaan regresi tersebut dapat diinterpretasikan bahwa jika supervisi manajerial kepala sekolah (X1) dan prestasi kerja guru (Y) diukur dengan instrumen yang dikembangkan dalam penelitian ini, maka setiap perubahan skor supervisi manajerial kepala sekolah sebesar satu satuan dapat diestimasikan skor prestasi kerja guru akan berubah 0,139 satuan pada arah yang sama.

Berdasarkan temuan empirik yang menunjukkan adanya pengaruh yang positif dan signifikan supervisi manajerial kepala sekolah terhadap prestasi kerja guru, maka hasil penelitian ini memberikan beberapa informasi, di antaranya: (1) Pelaksanaan supervisi manajerial kepala sekolah pada SDN di UPTD Pendidikan Kecamatan Ciawigebang Kabupaten Kuningan memberikan pengaruh yang berarti terhadap prestasi kerja guru, (2) Salah satu cara untuk meningkatkan prestasi kerja guru pada SDN di UPTD Pendidikan Kecamatan Ciawigebang Kabupaten Kuningan adalah dengan meningkatkan pelaksanaan supervisi manajerial kepala sekolah, serta (3) Kontribusi yang diberikan oleh pengaruh supervisi manajerial kepala sekolah terhadap prestasi kerja guru pada SDN di UPTD Pendidikan Kecamatan Ciawigebang Kabupaten Kuningan adalah sebesar $7,3 \%$, sementara sisanya dipengaruhi oleh variabel lain, selain variabel iklim organisasi, yang tidak dikaji dalam penelitian ini (epsilon).

Kedua, pendidikan Kecamatan Ciawigebang Kabupaten Kuningan. Secara empirik, hasil penelitian ini menginformasikan: (1) terdapat pengaruh yang positif dan signifikan iklim organisasi terhadap prestasi kerja guru pada SDN di UPTD Pendidikan Kecamatan Ciawigebang Kabupaten Kuningan, serta (2) besarnya pengaruh iklim organisasi terhadap prestasi kerja guru pada SDN di UPTD Pendidikan Kecamatan Ciawigebang Kabupaten Kuningan ditunjukkan oleh hasil penelitian bahwa tingginya iklim organisasi yang terdiri dari dimensi: (1) hakekat manusia, (2) hubungan organisasional, dan (3) hubungan antar pribadi (Cooke and Nigel, 2005:92), membawa implikasi yang signifikan terhadap prestasi kerja guru yang meliputi dimensi: (1) kualitas hasil kerja, (2) ketepatan waktu, (3) inisiatif dalam 
pekerjaan,

kemampuan menyelesaikan tugas, dan (5) kemampuan bekerjasama

(Mitchel

dalam

Sedarmayanti, 1998:51).

Dengan demikian, hasil penelitian ini mengindikasikan bahwa semakin tinggi (bagus) iklim organisasi pada SDN di UPTD Pendidikan Kecamatan Ciawigebang Kabupaten Kuningan, maka akan diikuti oleh semakin tingginya prestasi kerja guru. Hal ini dapat diterangkan oleh persamaan regresi $\mathrm{Y}=$ $53,178+0,144 X 2$. Dengan persamaan regresi tersebut dapat diinterpretasikan bahwa jika iklim organisasi (X2) dan prestasi kerja guru (Y) diukur dengan instrumen yang dikembangkan dalam penelitian ini, maka setiap perubahan skor iklim organisasi sebesar satu satuan dapat diestimasikan skor prestasi kerja guru akan berubah 0,144 satuan pada arah yang sama.

Berdasarkan temuan empirik yang menunjukkan adanya pengaruh yang signifikan iklim organisasi terhadap prestasi kerja guru, maka hasil penelitian ini memberikan beberapa informasi, di antaranya: (1) Iklim organisasi SDN di UPTD Pendidikan Kecamatan Ciawigebang Kabupaten Kuningan memberikan pengaruh yang berarti terhadap prestasi kerja guru, (2) Salah satu cara untuk meningkatkan prestasi kerja guru pada SDN di UPTD Pendidikan Kecamatan Ciawigebang Kabupaten Kuningan adalah dengan meningkatkan iklim organisasi, serta (3) Kontribusi yang diberikan oleh pengaruh iklim organisasi terhadap prestasi kerja guru adalah sebesar 6,2\%, sementara sisanya dipengaruhi oleh variabel lain, selain variabel supervisi manajerial kepala sekolah, yang tidak dikaji dalam penelitian ini (epsilon).

Ketiga, Permasalahan yang ingin dijawab dalam penelitian ini adalah adakah pengaruh supervisi manajerial kepala sekolah dan iklim organisasi secara simultan terhadap prestasi kerja guru pada SDN di UPTD Pendidikan Kecamatan Ciawigebang Kabupaten Kuningan. Secara empirik, hasil penelitian ini menginformasikan: (1) terdapat pengaruh yang positif dan signifikan supervisi manajerial kepala sekolah dan iklim organisasi secara simultan terhadap prestasi kerja guru pada SDN di UPTD Pendidikan Kecamatan Ciawigebang Kabupaten Kuningan, serta (2) besarnya pengaruh supervisi manajerial kepala sekolah dan iklim organisasi secara simultan terhadap prestasi kerja guru pada SDN di UPTD Pendidikan Kecamatan Ciawigebang Kabupaten Kuningan ditunjukkan oleh hasil penelitian bahwa supervisi 
manajerial kepala sekolah yang terdiri dari dimensi: (1) memantau, mensupervisi, (3) menilai, (4) membina, dan (5) melaporkan (Masyhud, 2012), serta iklim organisasi yang terdiri dari dimensi: (1) hakekat manusia, (2) hubungan organisasional, dan (3) hubungan antar pribadi (Cooke and Nigel, 2005:92), membawa implikasi yang signifikan terhadap prestasi kerja guru yang meliputi dimensi: (1) kualitas hasil kerja, (2) ketepatan waktu, (3) inisiatif dalam pekerjaan, (4) kemampuan menyelesaikan tugas, dan (5) kemampuan bekerjasama (Mitchel dalam Sedarmayanti, 1998:51). Namun demikian prestasi kerja guru pada SDN di UPTD Pendidikan Kecamatan Ciawigebang Kabupaten Kuningan tidak hanya dipengaruhi oleh supervisi manajerial kepala sekolah dan iklim organisasi saja, melainkan ada faktor lain (epsilon), yang juga berpengaruh, yang tidak dikaji dalam penelitian ini.

Dalam konteks pengajaran, Hariwung dalam Rusli (2002:112) mendefinisikan supervisi adalah sebagai suatu usaha untuk mendorong, mengkoordinasikan, dan membimbing pertumbuhan guru secara berkesinambungan di suatu sekolah, baik secara individual maupun kelompok. Dari pendapat di atas dapat dikatakan bahwa supervisi adalah suatu kegiatan yang mendorong, membimbing, dan mengawasi kegiatan--kegiatan guru secara berkesinambungan di suatu sekolah.

Selanjutnya, masih dalam konteks supervisi pengajaran Alfonso sebagaimana dikutip Rusli (2002:112) mengemukakan bahwa definisi supervisi pendidikan adalah "Instructional supervision is here in defined as: behavior in such a way as to facilitate pupil teaming and achieve the goals of organization". Dengan demikian bahwa supervisi pengajaran dapat didefinisikan perilaku yang dirancang secara resmi oleh organisasi yang secara langsung mempengaruhi perilaku guru sedemikian rupa sehingga memudahkan murid murid belajar dan mencapai tujuan sekolah.

Dengan demikian, hasil penelitian ini mengindikasikan bahwa semakin bagus supervisi manajerial kepala sekolah dan iklim organisasi secara simultan pada SDN di UPTD Pendidikan Kecamatan Ciawigebang Kabupaten Kuningan, maka akan diikuti oleh semakin tingginya prestasi kerja guru. Hal ini dapat diterangkan oleh persamaan regresi $\hat{Y}=$ $43,098+0,135 X 1+0,140 X 2$. Dengan persamaan regresi tersebut dapat diinterpretasikan bahwa jika supervisi manajerial kepala sekolah (X1), dan iklim organisasi (X2) serta prestasi kerja 
guru (Y) diukur dengan instrumen yang dikembangkan dalam penelitian ini, maka setiap perubahan skor pelaksanaan supervisi manajerial kepala sekolah, dan iklim organisasi secara simultan sebesar satu satuan dapat diestimasikan skor prestasi kerja guru akan berubah 0,135 dan 0,140 satuan pada arah yang sama.

Berdasarkan temuan empirik yang menunjukkan adanya pengaruh yang positif dan signifikan supervisi manajerial kepala sekolah dan iklim organisasi terhadap prestasi kerja guru, maka hasil penelitian ini memberikan beberapa informasi, di antaranya: (1) Pelaksanaan supervisi manajerial kepala sekolah dan iklim organisasi pada SDN di UPTD Pendidikan Kecamatan Ciawigebang Kabupaten Kuningan memberikan pengaruh yang berarti terhadap prestasi kerja guru pada SDN di UPTD Pendidikan Kecamatan Ciawigebang Kabupaten Kuningan, (2) Salah satu cara untuk meningkatkan prestasi kerja guru pada SDN di UPTD Pendidikan Kecamatan Ciawigebang Kabupaten Kuningan adalah dengan meningkatkan supervisi manajerial kepala sekolah dan iklim organisasi. (3) Kontribusi yang diberikan oleh supervisi manajerial kepala sekolah dan iklim organisasi secara bersama-sama terhadap prestasi kerja guru pada SDN di UPTD
Pendidikan Kecamatan Ciawigebang Kabupaten Kuningan adalah sebesar $13,1 \%$, sementara sisanya dipengaruhi oleh variabel lain, yang tidak dikaji dalam penelitian ini (epsilon).

\section{PENUTUP}

Setelah mengadakan penelitian yang berkaitan dengan supervisi manajerial kepala sekolah, iklim organisasi dan pengaruhnya terhadap prestasi kerja guru maka penulis dapat mengambil kesimpulan sebagai berikut:

1) Terdapat pengaruh yang positif dan signifikan supervisi manajerial kepala sekolah terhadap prestasi kerja guru SD Negeri pada UPTD Pendidikan di Kecamatan Ciawigebang Kabupaten Kuningan. Besaran pengaruhnya melalui perhitungan regresi parsial sebesar 7,3\%, sementara selebihnya sebanyak 92,7\% merupakan pengaruh lain.

2) Terdapat pengaruh yang positif dan signifikan iklim organisasi terhadap prestasi kerja guru SD Negeri pada UPTD Pendidikan di Kecamatan Ciawigebang Kabupaten Kuningan. Besaran pengaruhnya melalui perhitungan regresi parsial sebesar 6,2\%, sementara selebihnya sebanyak 93,8\% merupakan pengaruh lain.

3) Terdapat pengaruh yang positif dan signifikan supervisi manajerial 
kepala sekolah dan iklim organisasi secara simultan terhadap prestasi kerja guru SD Negeri pada UPTD Pendidikan di Kecamatan Ciawigebang Kabupaten Kuningan. Besaran pengaruhnya melalui perhitungan regresi ganda sebesar 13,1 $\%$, sementara selebihnya sebanyak 86,9 $\%$ merupakan pengaruh lain.

\section{UCAPAN TERIMAKASIH}

Terima kasih kami ucapkan kepada semua pihak yang telah membantu penulisan karya ilmiah ini.

\section{DAFTAR PUSTAKA}

Ali, Mohammad et al, (2007), Ilmu dan Aplikasi Pendidikan, Paedagogiana Press,

Anoraga, Pandji. (2005). Manajemen Bisnis, Cetakan Ketiga. Jakarta: Rineka Cipta.

Burhanuddin. (1994). Analisis Administrasi Manajemen dan Kepemimpinan Pendidikan. Jakarta: Bumi Aksara.

Davis, Keith. (1982). Human Behavior at Work. Organizational Behavior Metro. Manila: McGraw Hill, Inc.

Fraser, T.M., (2005). Stress dan Kepuasan Kerja. Jakarta: PT Sapdodadi.

Moon, H.K. \& Choi, B.K. (2014). How an Organizations Ethical Climate Contributes to Customer Satisfaction and Financial Performance. European Journal of
Innovation Management ISSN: $1460-1060$

Musanef. (2005). Manajemen Kepegawaian di Indonesia. Jakarta: Gunung Agung.

Nainggolan, H. (2005). Pembinaan Pegawai Sipil. Jakarta: PT. Nuttu.

Purwanto, Iwan. 2007, Manajemen Strategi, Bandung: Yrama Widya.

Ruky, Achmad S. (2001). Sistem Manajemen Kinerja. Jakarta: PT Gramedia.

Sahertian, Piet A. (2000). Konsep-Konsep dan Teknik Supervisi Pendidikan Dalam Rangka Pengembangan Sumber Daya Manusia. Jakarta: Rineka Cipta.

Willam B. Wheater Jr. and Keith Davis, 1978, Human Resources and Personel Management, fifth edition. New York: McGraw-Hill, Inc. 